\title{
An Observational Study of Variation in the Pulmonary Functions with the Phases of Menstrual Cycle in Females of Different Age Groups
}

\author{
Sheeba Shaheen ${ }^{1}$, Vibha Gangwar ${ }^{2, *}$, Nitin Ashok John², Shweta Gupta ${ }^{2}$
}

\section{Sheeba Shaheen ${ }^{1}$, Vibha Gangwar ${ }^{2, *}$, Nitin Ashok John², Shweta Gupta ${ }^{2}$}

\begin{abstract}
${ }^{1}$ MBBS Students, Dr. Ram Manohar Lohia Institute of Medical Sciences, Vibhuti Khand, Gomti Nagar, Lucknow, Uttar Pradesh, INDIA.

${ }^{2}$ Department of Physiology, Academic Block, Dr. Ram Manohar Lohia Institute of Medical Sciences, Vibhuti Khand, Gomti Nagar, Lucknow, Uttar Pradesh, INDIA.
\end{abstract}

\section{*Correspondence}

\section{Dr. Vibha Gangwar}

Assistant Professor, Department of Physiology, Academic Block, Dr. Ram Manohar Lohia Institute of Medical Sciences, Vibhuti Khand, Gomti Nagar, Lucknow, Uttar Pradesh, INDIA.

Phone: +91-9412566505

Email:vgangwar.vg@gmail.com

History

- Submission Date: 27-12-2019;

- Review completed: 13-02-2020;

- Accepted Date: 10-03-2020.

DOI : 10.5530/ijcep.2020.7.1.6

Article Available online

http://www.ijcep.org

\section{Copyright}

(C) 2020 Phcog.Net. This is an openaccess article distributed under the terms of the Creative Commons Attribution 4.0 International license.

\begin{abstract}
Background and Aim: Many evidences are available showing influence of estrogen and progesterone on respiratory function. Still, there is no clear picture of this. Therefore, we aimed this study to evaluate the pulmonary functions in various phases of menstrual cycle in females of different age groups. Methods: Sixty healthy females with normal menstrual cycle participated in study. They were divided into 3 groups of 20 females each. The age ranged between 15-25, 26-35 and 36-45 years in group I, II and III respectively. Their pulmonary functions were measured in menstrual, follicular and secretary phase of a single cycle after taking detailed history and preliminary examination. Results: There was no significant difference in pulmonary functions in all the three phases of menstrual cycle between the groups. In menstrual phase, ratio of forced expiratory volume in first sec and forced vital capacity (FEV1/FVC) FEV1/FVC ratio while in follicular phase, forced expiratory volume in first sec (FEV1), FEV1/FVC ratio and and forced expiratory flow during $25 \%$ to $75 \%$ of expiration $\left(\mathrm{FEF}_{25-75 \%}\right)$ were significantly higher in group I than other groups. No significant difference was found in parameters in secretary phase between three groups. Conclusion: Pulmonary functions didn't change with the phases of menstrual cycle contradicting the results of previous studies. Pulmonary functions in terms of FEV1 and FEV1/FVC ratio and FEF $25-75 \%$ were significantly better in menstrual phase and follicular phase in age groups of $15-25$ years than older age groups.

Key words: Follicular phase, Menstrual phase, Secretary phase, Pulmonary functions, Age group.
\end{abstract}

\section{INTRODUCTION}

Menstrual cycle includes the duration from the first day of menstrual bleeding of one cycle to the first day of menstrual bleeding of next cycle with an average duration of 28 days. ${ }^{[1]}$ It is divided into menstrual, proliferative and secretary phase. ${ }^{[2]}$ The proliferative phase lasts for 1-14 days which also includes menstrual phase (1-5 days) and secretary phase starts from fifteenth day and lasts at the onset of next menstrual phase. ${ }^{[3]}$ Rhythm of menstrual cycle is controlled by Gonadotropin Releasing Hormone (GnRH), Luteinizing Hormone (LH) and Follicular Stimulating Hormone (FSH) secreted from hypothalamo-pituitary axis and oestrogen and progesterone secreted from ovary ${ }^{[4]}$ Fluctuation in the level of these hormones in menstrual cycle affects not only reproductive system but also the functional parameters of other systems including brain, musculoskeletal system, cardiovascular system and respiratory system. ${ }^{[5]}$ Progesterone which is secreted in secretary phase after ovulation, relaxes smooth muscles in gut, genitourinary tract, vascular tree and bronchial smooth muscles. It is known to strengthen the smooth bronchial muscles. It stimulates respiration

by stimulating the respiratory centres. ${ }^{[6]}$ The alveolar $\mathrm{PO}_{2}$ is in males is more than the females during the luteal phase. ${ }^{[1]}$ It may also have some effect on the physical performance and $\mathrm{VO}_{2}$ max..$^{[7]}$

Respiratory diseases are the third leading cause of death (9.2\% of total deaths) in India as reported in $2017 .^{[8]}$ Although there are various pathophysiological factors affecting chronic respiratory diseases, women are increasingly affected from these disorders for unknown reasons. The frequency of asthma and allergic diseases is greater in girls than boys around puberty and thereafter. ${ }^{[9]}$ The hormonal changes and other factors during adolescence may contribute to it. Symptoms of asthma aggravate during the premenstrual or menstrual phase of menstrual cycle in some female patients. ${ }^{[10]}$ These data suggest that female gender is an important risk factor for respiratory diseases and there is a possibility of role of female hormones in mediating these diseases but the exact physiology behind this is still not known.

Differences in pulmonary functions between males and females are present throughout life and have

Cite this article: Shaheen S, Gangwar V, John NA, Gupta S. An Observational Study of Variation in the Pulmonary Functions with the Phases of Menstrual Cycle in Females of Different Age Groups. Int J Clin Exp Physiol. 2020;7(1):22-6. 
been associated with sex specific responses to environmental and lifestyle insults and sex hormones. ${ }^{[11,12]}$ The Isparta Menopause and Health study found that lower FEV1 and FVC was associated with menopause and this was explained by age. ${ }^{[13]}$

Many studies have been done to evaluate the effect of various phases of menstrual cycle on pulmonary functions but the clear picture is not available. Also, changes in pulmonary functions in different phase of menstrual cycle with age are not studied till now.

Therefore, we planned this study with the hypothesis that hormonal changes in various phases of menstrual cycle cause change in respiratory functions too and increasing age may have a negative effect on these changes, based on the previous researches.

\section{MATERIALS AND METHODS}

This observational prospective study was done as a project of shortterm studentship under Indian Council of Medical Research, in the department of physiology, Dr. Ram Manohar Lohia Institute of medical sciences, Lucknow, India from May 2019 to September 2019. Sixty apparently healthy females with normal regular menstrual cycle of twentyeight days were selected to participate in the study by simple random sampling technique. Subjects having history of any pelvic pathology, menstrual irregularity, long term medication, use of oral contraceptives, smoking, current pregnancy, pulmonary and endocrine disorder were excluded from the study. As this work involved human subjects, it had been done in accordance with the code of ethics of the world medical association (Declaration of Helsinki) and was approved by ethics committee of institute. A written consent was obtained from all the subjects after explaining the procedure and their privacy rights were considered properly. All the participants were divided into three groups of 20 subjects each according to their age. The age ranged between 15 to 45 years, 26 to 35 years and 36 to 45 years in group I, II and III respectively. The participants were asked to fill a detailed questionnaire to assess their medical history. Their height, weight, pulse and blood pressure was recorded. BMI was calculated with the help of Quetlet's index. Their menstrual history was recorded specially containing date of last menstrual cycle, dates of last three consecutive menstrual cycles and duration of menses. The probable date of ovulation was calculated by the date of onset of menstruation, based upon which different phases of menstrual cycle were determined. Follicular phase was calculated as the $4^{\text {th }}$ day of the present cycle, ovulatory phase 14 day prior to the onset of next cycle and luteal phase as the period after ovulation to the onset of next menstrual cycle. The subjects were asked to report three times: between $2^{\text {nd }}$ and $4^{\text {th }}$ day (menstrual phase), $10^{\text {th }}$ and $12^{\text {th }}$ day (follicular phase) and $22^{\text {nd }}$ and 24 th day (secretary phase) of a single menstrual cycle in the morning hours between 11.00 am to $1.00 \mathrm{pm}$.

Pulmonary functions were assessed with the help of "Easy On PC" spirometer [ndd Medical Technologies, Inc. MA] with software named "Easy Connect" in all the three phases. The subjects were explained the whole procedure in detail. They were made to sit on a stool and were asked to inhale to their maximum ability. Then mouthpiece was placed between the lips creating air tight seal. The nose clip was attached and the subjects were to do a maximum forced and rapid expiration followed by rapid forced inspiration. The procedure was performed for three times and the machine gave best manoeuvre result.

\section{Statistical Analysis of Data}

Data were expressed as mean \pm standard deviation. Comparison of pulmonary function tests in various phases of menstrual cycle in various groups were done by ANOVA (Analysis of variance) test with the help of Excel's statistics tool. $P$ value less than 0.05 was considered as significant.

\section{RESULTS}

This study included sixty female subjects from the staff of Dr. Ram Manohar Lohia Institute of Medical sciences, Lucknow. They were divided into three groups according to their age. The mean age of the participants was $19.55 \pm 2.74$ years, $30.56 \pm 2.71$ years and $38.79 \pm 2.78$ years. Their mean BMI was $20.76 \pm 4.09,21.98 \pm 3.40$ and $21.95 \pm 3.44 \mathrm{~kg} / \mathrm{m} 2$ in group 1,2 and 3 respectively (Table 1 ).

The parameters of pulmonary function tests in menstrual, proliferative and secretary phase were similar in all the groups and there was no significant difference (Table 2).

Pulmonary functions were also compared between all the groups in menstrual, proliferative and secretary phases separately. In menstrual phase, there was no significant difference in all parameters except FEV1/ FVC ratio which significantly females of group 1 than group 2 and 3 $(P=0.004)$. In proliferative phase, the mean FEV1, FEV1/FVC and $\mathrm{FEF}_{25}$ ${ }_{75 \%}$ were significantly higher in group 1 than group 2 and $3(P=0.034$, $P=0.001$ and $P=0.007$ respectively). No significant difference was found in other parameters. There was no significant difference in pulmonary functions in luteal phase between all the groups $(P>0.05)$ (Table 3$)$.

\section{DISCUSSION}

Many studies have been done to evaluate the effect of menstrual cycle on lung functions which involved the young girls ${ }^{[14-18]}$ but we included subjects of three age groups viz 15-25 years, 26 - 35 years and 36-45 years in our study and evaluated the changes of pulmonary functions in all these age groups.

We determined the phases of menstrual cycle on the basis of duration of the menstrual cycle as done in other studies ${ }^{[16,19]}$ but some studies confirmed these phases by serum progesterone and estrogen levels. ${ }^{[20]}$

We found no significant change in lung functions in various phases of menstrual cycle in our study and contradicted the results of previous studies in which the lung functions were better in secretary phase than that of menstrual and follicular phase. ${ }^{[15-18,21]}$ However, some studies also found results similar to our study. ${ }^{[22]}$ Pauli BD et al. found premenstrual worsening of asthma symptoms and Peak Expiratory Flow Rate (PEFR) but they did not relate these changes to the deterioration in spirometry and airway reactivity or to the absolute levels of circulating progesterone and estradiol. ${ }^{[23]}$

Mannan et al. found significantly increased FEV1, FVC and FEV1/FVC in luteal phase than follicular and menstrual phase in their study. The $P$ value was $<0.001$. They attributed this change to higher concentration of plasma progesterone level in secretary phase which relaxes the bronchial smooth muscle. ${ }^{[24]}$ In our study, there was no change in FEV1, FVC and FEV1/FVC ratio with the phases of menstrual cycle. Timon $\mathrm{R}$ et al. and Da Silva SB also reported no changes in FVC and FEV1 during the different phases of menstrual cycle. ${ }^{[22,25]}$ These results can be explained on the basis of study done by Hayes et al. who reported that estrogen could affect central nervous activity but not peripheral reflexes which are involved in respiratory mechanism. ${ }^{[26]}$

Table 1: Anthropometric parameters of the subjects.

\begin{tabular}{ccccc} 
Parameters & $\begin{array}{c}\text { Group 1 } \\
\text { (Mean } \pm \text { SD) }\end{array}$ & $\begin{array}{c}\text { Group 2 } \\
\text { (Mean } \pm \text { SD) }\end{array}$ & $\begin{array}{c}\text { Group 3 } \\
\text { (Mean } \pm \text { SD) }\end{array}$ & 1P-Value \\
\hline Weight (Kg) & $50.41 \pm 13.12$ & $52.25 \pm 10.56$ & $51.11 \pm 8.81$ & 0.881 \\
$\begin{array}{c}\text { Height (meters) } \\
\text { Body mass index } \\
\left(\mathbf{k g} / \mathbf{m}^{2}\right)\end{array}$ & $154.95 \pm 7.14$ & $153.67 \pm 4.95$ & $152.42 \pm 4.49$ & 0.383 \\
\hline
\end{tabular}


Table 2: Pulmonary functions in different phases of menstrual cycle in group 1, 2 and 3.

\begin{tabular}{|c|c|c|c|c|c|}
\hline \multicolumn{2}{|l|}{ Parameter } & \multirow{2}{*}{$\begin{array}{c}\text { Menstrual phase } \\
\text { Mean } \pm \text { SD } \\
2.13 \pm 0.56\end{array}$} & \multirow{2}{*}{$\begin{array}{c}\text { Follicular phase } \\
\text { Mean } \pm \text { SD } \\
2.15 \pm 0.53\end{array}$} & \multirow{2}{*}{$\begin{array}{c}\text { Secretary phase } \\
\text { Mean } \pm \text { SD } \\
2.01 \pm 0.56\end{array}$} & \multirow{2}{*}{$\begin{array}{c}{ }^{1} P \text { value } \\
0.676\end{array}$} \\
\hline FEV1 (L) & Group 1 & & & & \\
\hline & Group 2 & $1.93 \pm 0.37$ & $1.98 \pm 0.28$ & $2.02 \pm 0.34$ & 0.776 \\
\hline & Group 3 & $1.82 \pm 0.41$ & $1.78 \pm 0.40$ & $1.90 \pm 0.40$ & 0.695 \\
\hline \multirow[t]{3}{*}{ FVC (L) } & Group 1 & $2.47 \pm 0.63$ & $2.47 \pm 0.63$ & $2.34 \pm 0.68$ & 0.759 \\
\hline & Group 2 & $2.38 \pm 0.38$ & $2.39 \pm 0.38$ & $2.48 \pm 0.40$ & 0.733 \\
\hline & Group 3 & $2.32 \pm 0.43$ & $2.26 \pm 0.45$ & $2.38 \pm 0.42$ & 0.715 \\
\hline \multirow[t]{3}{*}{ FEV1/FVC } & Group 1 & $86.32 \pm 6.4$ & $87.00 \pm 6.63$ & $85.85 \pm 8.69$ & 0.875 \\
\hline & Group 2 & $81.02 \pm 6.93$ & $83.41 \pm 5.70$ & $83.01 \pm 5.44$ & 0.534 \\
\hline & Group 3 & $78.12 \pm 8.40$ & $78.69 \pm 7.35$ & $79.39 \pm 7.95$ & 0.904 \\
\hline \multirow[t]{3}{*}{$\mathrm{FEF}_{25-75 \%}(\mathrm{~L} / \mathrm{S})$} & Group 1 & $2.49 \pm 0.88$ & $2.57 \pm 0.78$ & $2.40 \pm 0.89$ & 0.815 \\
\hline & Group 2 & $2.17 \pm 0.82$ & $2.24 \pm 0.55$ & $2.27 \pm 0.62$ & 0.931 \\
\hline & Group 3 & $1.83 \pm 0.70$ & $1.83 \pm 0.72$ & $1.97 \pm 0.82$ & 0.831 \\
\hline \multirow[t]{3}{*}{$\operatorname{PEF}(\mathrm{L} / \mathrm{S})$} & Group 1 & $4.40 \pm 1.47$ & $5.91 \pm 7.07$ & $4.08 \pm 1.31$ & 0.345 \\
\hline & Group 2 & $3.93 \pm 1.47$ & $4.40 \pm 1.16$ & $4.35 \pm 1.26$ & 0.570 \\
\hline & Group 3 & $4.01 \pm 1.10$ & $4.05 \pm 1.23$ & $4.43 \pm 1.29$ & 0.575 \\
\hline \multirow[t]{3}{*}{ FIVC (L) } & Group 1 & $2.47 \pm 0.77$ & $2.44 \pm 0.61$ & $2.54 \pm 0.65$ & 0.897 \\
\hline & Group 2 & $2.48 \pm 0.44$ & $2.39 \pm 0.52$ & $2.49 \pm 0.42$ & 0.832 \\
\hline & Group 3 & $2.37 \pm 0.40$ & $2.34 \pm 0.57$ & $2.40 \pm 0.44$ & 0.957 \\
\hline \multirow[t]{3}{*}{$\operatorname{PIF}(\mathrm{L} / \mathrm{S})$} & Group 1 & $3.21 \pm 1.12$ & $3.17 \pm 1.11$ & $3.26 \pm 1.12$ & 0.970 \\
\hline & Group 2 & $3.17 \pm 1.08$ & $2.94 \pm 0.87$ & $3.10 \pm 0.67$ & 0.771 \\
\hline & Group 3 & $2.96 \pm 0.87$ & $2.89 \pm 1.06$ & $3.18 \pm 1.26$ & 0.729 \\
\hline \multirow[t]{3}{*}{$\mathrm{VC}(\mathrm{L})$} & Group 1 & $2.49 \pm 0.69$ & $2.51 \pm 0.64$ & $2.43 \pm 0.7$ & 0.932 \\
\hline & Group 2 & $2.37 \pm 0.42$ & $2.45 \pm 0.42$ & $2.38 \pm 0.46$ & 0.858 \\
\hline & Group 3 & $2.17 \pm 0.44$ & $2.13 \pm 0.50$ & $2.23 \pm 0.49$ & 0.851 \\
\hline \multirow[t]{3}{*}{$\mathbf{R V}(\mathrm{L})$} & Group 1 & $1.14 \pm 0.39$ & $1.04 \pm 0.41$ & $1.10 \pm 0.4$ & 0.708 \\
\hline & Group 2 & $1.10 \pm 0.38$ & $1.15 \pm 0.26$ & $1.14 \pm 0.32$ & 0.929 \\
\hline & Group 3 & $1.03 \pm 0.39$ & $0.99 \pm 0.49$ & $0.85 \pm 0.40$ & 0.474 \\
\hline \multirow{3}{*}{$\begin{array}{c}\text { Tidal } \\
\text { volume }(\mathrm{L})\end{array}$} & Group 1 & $0.53 \pm 0.21$ & $0.62 \pm 0.22$ & $0.56 \pm 0.2$ & 0.345 \\
\hline & Group 2 & $0.55 \pm 0.21$ & $0.52 \pm 0.23$ & $0.69 \pm 0.52$ & 0.399 \\
\hline & Group 3 & $0.60 \pm 0.25$ & $0.57 \pm 0.19$ & $0.61 \pm 0.19$ & 0.793 \\
\hline
\end{tabular}

Dabhoiwala $S$ et al. reported no significant difference in FEF25-75\% in various phases of menstrual cycle which was similar to the result of our study. ${ }^{[19]}$ Gokhle et al. and Nandhini $\mathrm{R}$ et al. found a significantly increased $\mathrm{FEF}_{25-75 \%}$ in secretary phase due to relaxation of bronchial smooth muscles in luteal phase. ${ }^{[5,27]}$

PEF measures the airflow through the bronchi and thus degree of obstruction in airways. Rajesh CS, ${ }^{[7]}$ Handergulle SM et al. ${ }^{[15]}$ Kaur $\mathrm{H}^{[17]}$ Gavali $\mathrm{MY}^{[28]}$ and Arora $\mathrm{D}^{[29]}$ reported increased PEFR in luteal phase than the menstrual and follicular phase while our study didn't find any significant difference in PEFR in various phases of menstrual cycle.

We also measured vital capacity, residual volume and tidal volume in our study but found no significant change in these parameters with the phases of menstrual cycle. Other studies didn't measure these parameters.
We also studied the changes in pulmonary functions during menstrual cycle in various groups. No other study has done to compare pulmonary functions in different age groups. We found significantly better FEV1/ FVC ratio in age group of 15-25 years in menstrual and proliferative phase but no difference in secretary phase. In proliferative phase, FEV1 and $\mathrm{FEF}_{25-75 \%}$ were also better in age group of 15-25 years than other age groups. These changes can be explained on the basis of structural changes in airway as well as in muscles and lung functions associated with ageing ${ }^{[30]}$ Aging also causes alterations in carotid chemoreceptors, respiratory neuronal circuits and cellular and molecular events that accompany the aging process. ${ }^{[31,32]}$ Young neurons respond to sex hormones differently from aged neurons. 


\begin{tabular}{|c|c|c|c|c|c|}
\hline \multirow[t]{2}{*}{ Parameter } & & Group 1 & Group 2 & Group 3 & ${ }^{1} P$ value \\
\hline & & Mean \pm SD $(n=20)$ & $\begin{array}{c}\text { Mean } \pm \text { SD } \\
(n=20)\end{array}$ & $\begin{array}{c}\text { Mean } \pm \text { SD } \\
(n=20)\end{array}$ & \\
\hline \multirow[t]{3}{*}{ FEV1 (L) } & Menstrual phase & $2.13 \pm 0.56$ & $1.93 \pm 0.37$ & $1.82 \pm 0.41$ & 0.137 \\
\hline & Proliferative phase & $2.15 \pm 0.53$ & $1.98 \pm 0.28$ & $1.78 \pm 0.40$ & $0.034^{*}$ \\
\hline & Secretary phase & $2.01 \pm 0.56$ & $2.02 \pm 0.34$ & $1.90 \pm 0.40$ & 0.726 \\
\hline \multirow[t]{3}{*}{ FVC (L) } & Menstrual phase & $2.47 \pm 0.63$ & $2.38 \pm 0.38$ & $2.32 \pm 0.43$ & 0.683 \\
\hline & Proliferative phase & $2.47 \pm 0.63$ & $2.39 \pm 0.38$ & $2.26 \pm 0.45$ & 0.425 \\
\hline & Secretary phase & $2.34 \pm 0.68$ & $2.48 \pm 0.40$ & $2.38 \pm 0.42$ & 0.753 \\
\hline \multirow[t]{3}{*}{ FEV1/FVC } & Menstrual phase & $86.32 \pm 6.40$ & $81.02 \pm 6.93$ & $78.12 \pm 8.40$ & $0.004^{*}$ \\
\hline & Proliferative phase & $87.00 \pm 6.63$ & $83.41 \pm 5.70$ & $78.69 \pm 7.35$ & $0.001^{*}$ \\
\hline & Secretary phase & $85.85 \pm 8.69$ & $83.01 \pm 5.44$ & $79.39 \pm 7.95$ & 0.058 \\
\hline \multirow{3}{*}{$\begin{array}{l}\text { FEF }_{25-75 \%} \\
(\mathrm{~L} / \mathrm{S})\end{array}$} & Menstrual phase & $2.49 \pm 0.88$ & $2.17 \pm 0.82$ & $1.83 \pm 0.70$ & 0.058 \\
\hline & Proliferative phase & $2.57 \pm 0.78$ & $2.24 \pm 0.55$ & $1.83 \pm 0.72$ & $0.007^{*}$ \\
\hline & Secretary phase & $2.35 \pm 0.90$ & $2.27 \pm 0.62$ & $1.97 \pm 0.82$ & 0.365 \\
\hline \multirow[t]{3}{*}{ PEF (L/S) } & Menstrual phase & $4.40 \pm 1.47$ & $3.93 \pm 1.47$ & $4.01 \pm 1.10$ & 0.549 \\
\hline & Proliferative phase & $5.91 \pm 7.07$ & $4.40 \pm 1.16$ & $4.05 \pm 1.23$ & 0.402 \\
\hline & Secretary phase & $4.08 \pm 1.31$ & $4.35 \pm 1.26$ & $4.43 \pm 1.29$ & 0.712 \\
\hline \multirow[t]{3}{*}{ FIVC (L) } & Menstrual phase & $2.47 \pm 0.77$ & $2.48 \pm 0.44$ & $2.37 \pm 0.40$ & 0.839 \\
\hline & Proliferative phase & $2.44 \pm 0.61$ & $2.39 \pm 0.52$ & $2.34 \pm 0.57$ & 0.877 \\
\hline & Secretary phase & $2.54 \pm 0.65$ & $2.49 \pm 0.42$ & $2.39 \pm 0.44$ & 0.740 \\
\hline \multirow[t]{3}{*}{ PIF (L/S) } & Menstrual phase & $3.21 \pm 1.12$ & $3.17 \pm 1.08$ & $2.96 \pm 0.87$ & 0.757 \\
\hline & Proliferative phase & $3.17 \pm 1.11$ & $2.94 \pm 0.87$ & $2.89 \pm 1.06$ & 0.650 \\
\hline & Secretary phase & $3.25 \pm 1.12$ & $3.10 \pm 0.67$ & $3.18 \pm 1.26$ & 0.912 \\
\hline \multirow[t]{3}{*}{$\operatorname{VC}(\mathrm{L})$} & Menstrual phase & $2.49 \pm 0.69$ & $2.37 \pm 0.42$ & $2.17 \pm 0.44$ & 0.241 \\
\hline & Proliferative phase & $2.51 \pm 0.64$ & $2.45 \pm 0.42$ & $2.13 \pm 0.50$ & 0.082 \\
\hline & Secretary phase & $2.43 \pm 0.67$ & $2.38 \pm 0.46$ & $2.23 \pm 0.49$ & 0.550 \\
\hline \multirow[t]{3}{*}{ RV (L) } & Menstrual phase & $1.14 \pm 0.39$ & $1.10 \pm 0.38$ & $1.03 \pm 0.39$ & 0.712 \\
\hline & Proliferative phase & $1.04 \pm 0.41$ & $1.15 \pm 0.26$ & $0.99 \pm 0.49$ & 0.551 \\
\hline & Secretary phase & $1.10 \pm 0.40$ & $1.14 \pm 0.32$ & $0.85 \pm 0.40$ & 0.080 \\
\hline \multirow{3}{*}{$\begin{array}{c}\text { Tidal volume } \\
\text { (L) }\end{array}$} & Menstrual phase & $0.53 \pm 0.21$ & $0.55 \pm 0.21$ & $0.60 \pm 0.25$ & 0.615 \\
\hline & Proliferative phase & $0.62 \pm 0.22$ & $0.52 \pm 0.23$ & $0.57 \pm 0.19$ & 0.369 \\
\hline & Secretary phase & $0.56 \pm 0.20$ & $0.69 \pm 0.52$ & $0.61 \pm 0.19$ & 0.506 \\
\hline
\end{tabular}

\section{CONCLUSION}

Our study concluded that

- There is no significant correlation of pulmonary functions with the phases of menstrual cycle thus it contradicts results of previous studies.

- $\quad$ FEV1 and FEV1/FVC ratio and $\mathrm{FEF}_{25-75 \%}$ are better in menstrual and follicular phase in age groups of 15-25 years than that in older age groups.

Continued research is needed to address the complex mechanisms on respiratory functions during different phases of menstrual cycle as the results of various studies are conflicting. Also, further studies should be done to understand the impact of sex hormones at different ages in menstrual cycle. We can customize and target hormone therapies for various respiratory disorders that affect females at various ages by understanding of how sex hormones affect respiratory control system.

\section{ACKNOWLEDGEMENT}

We are very thankful to the office staff and colleagues for their co-operation. We are also thankful to Dr. Arvind Kumar Singh, Associate Professor, Community Medicine for helping us in statistical analysis. This study was supported by Indian Council of Medical Research (ICMR), under the scheme of 'Short Term Studentship 2019'.

\section{CONFLICT OF INTEREST}

The authors declare no conflict of interest. 


\section{ABBREVIATIONS}

FEV1: Forced expiratory volume in first second; FVC: Forced vital capacity; $\mathbf{F E F}_{25-75 \%}$ : Forced expiratory flow during $25 \%$ to $75 \%$ of expiration; GnRH: Gonadotropin releasing hormone; LH: Luteinizing hormone; FSH: Follicular stimulating hormone; PEFR: Peak expiratory flow rate.

\section{REFERENCES}

1. Hall JE, Vaz M, Kurpad A, RajT. Female physiology before pregnancy and female hormones. In: Guyton and Hall Textbook of Medical Physiology. $2^{\text {nd }}$ edition. Elsevier. 2016;663-78.

2. Preston RR, Wilson TE. Female and Male Gonads. In: Lippincott's Illustrated Reviews Physiology. $1^{\text {st }}$ edition. New Delhi: Wolters Kluwer. 2013;438-48.

3. Berek JS. Berek and Novak's text book of Gynaecology. 15 $5^{\text {th }}$ South Asian Edition. 2016;644.

4. Barrett KE, Brooks H, Boitano S, Barman SM, Blotanon S. Reproductive development and functions of the female reproductive system. In: Ganong's Review of Medical Physiology. 25th edition. New Delhi: McGraw Hill. 2016;389-416.

5. Nandhini R, Subhashini AS. Variation in the pulmonary functions with the phases of the menstrual cycle in adolescent females. J Clin Diagnost Res. 2012;6(2):173-5.

6. Pal GK, Pal P, Nanda N. Ovarian hormones, control of ovarian functions and applied aspects. In Comprehensive Textbook of Medical Physiology. $2^{\text {nd }}$ edition. New Delhi/London/Panama. 2019;2:992-8

7. Rajesh CS, Gupta P, Vaney N. The status of the pulmonary function tests in adolescent females of Delhi. Indian J Physiol Pharmacol. 2000;44(4):442-8.

8. Report on medical certification of causes of death. 2017. Available from: www. cvensusindia.gov.in/medical

9. Shah R, Newcomb DC. Sex bias in asthma prevalence and pathogenesis. Front Immunol. 2018;9:2997.

10. Graziottin A, Serafini A. Perimenstrual asthma: From pathophysiology to treatment strategies. Multidiscip Respir Med. 2016;11(1):30.

11. Pinkerton KE, Harbaugh M, Han MK, Jourdan LSC, VanWinke LS, Martin WJ, et al. Women and lung disease. Sex differences and global health disparities. Am J Respir Crit Care Med. 2015;192(1):11-6.

12. Townsend EA, Miller VM, Prakash YS. Sex differences and sex steroids in lung health and disease. Endocr Rev. 2012;33(1):1-47.

13. Songur N, Aydin ZD, Ozturk O, Sahin U, Khayri U, Bircan A, et al. Respiratory symptoms, pulmonary functions and reproductive history: Isparta Menopause and Health Study. J Women Health. 2010;19(6):1145-54.

14. Goyal M, Dwivedi SK, Rajput AS. Effects of different phases of menstrual cycle on lung functions in young girls of 18-24 years age. Int J Res Med Sci. 2017;5(2):612-8.

15. Handergulle SM, Somani SS. Pulmonary functions tests in different phases of menstrual cycle in young girls of 18-22 years age. Nat J Bas Med Sci. 2017;8:103-7.

16. Nandhini R, Subhashini AS. Variation in the pulmonary functions with the phases of menstrual cycle in adolescent females. J Clin Diagn Res. 2012;6(2):173-5.

17. Kaur H, Kohli PG, Arora R, Maini S. Effect of different phases of menstrual cycle on pulmonary functions. Indian J Basic Appl Med Res. 2015;5:266-9.

18. Dudhamal VB, Satish. Lung function tests in different phases of menstrual cycle. Int J Med Res Rev. 2017;5(08):780-5.

19. Dabhoiwala S, Kathrotia R, Patel D, Dave A, Joshi A, Oommen E. Pulmonary functions in different phases of menstrual cycle and its relation with serum progesterone level. Nat J Integ Res Med. 2011;2:39-42.

20. Farha S, Asosingh K, Laskowski D, Hammel J, Dweik RA, Weidemann HP, et al. Effects of the menstrual cycle on lung function variables in women with asthma. Am J Resp Crit Care Med. 2009;180(4):304-10.

21. Kavitha JG, Chris AJ. Pulmonary function tests in different phases of menstrual cycle in young girls of Kanyakumari District. J Dental Med Sci. 2017;16(12):06-8.

22. Timon R, Balas AR, Adsuar JC, Delpozo-Cruz B, Maynar M. Reliability of spirometric tests during the different menstrual cycle phases in healthy women. Iranian J Publ Health. 2014;43(7):1009-10.

23. Pauli BD, Reid RL, Munt PW, Wigle RD, Forkert L. Influence of the menstrual cycle on airway functions in asthmatic and normal subjects. Am Rev Resp Dis. 1989;140(2):358-62.

24. Mannan SR, Begum N, Begum S, Ferdausi S, Ali T. Relationship of forced vital capacity (FVC) forced expiratory volume in first second (FEV1) and FEV/FVC\% with plasma progesterone level during different phases of normal menstrual cycle. J Bangladesh Soc Physiol. 2007;2:7-12.

25. DaSilva SB, DeSousa RVE, DeSousa MB. Changes in peak expiratory flow and respiratory strength during the menstrual cycle. Respir Physiol Neurobiol. 2006;150(2-3):211-9.

26. Hayes SG, Pino NB, Kaufman MP. Estrogen attenuates the cardiovascular and ventilatory responses to central command in cats. J Appl Physiol. 2002;92(4):1635-41.

27. Gokhale PA, Gokhale AV. Lung functions during different phases of menstrual cycle. The Indian Practitioner. 2002;55(6):353-6.

28. Gavali MY, Gavali XV, Gadkari JV, Patil KB. Influence of menstrual cycle on lung functions in young healthy medical students. Int $\mathrm{J}$ Healthcare Biomed Res. 2013;2(1):30-4

29. Arora DB, Sandhu PK, Dhillon S, Arora A, Kaur N. Respiratory functions in asthmatic and normal women during different phases of menstrual cycle. Pak J Physiol. 2015;11(2):3-7.

30. Jansen JP, Pache JC, Nicod LP. Physiological changes in respiratory function associated with ageing. Eur Resp J. 1999;13(1):197-205

31. Conde SV, Obeso A, Rigual R, Monteiro EC, Gonzalez C. Function of the rat carotid body chemoreceptors in ageing. J Neurochem. 2006;99(3):711-23.

32. Seebart BR, Stoffel RT, Behan M. Age-related Changes in the Serotonin 2A Receptor in the Hypoglossal Nucleus of Male and Female Rats. Resp Physiol Neurobiol. 2007:158(1):14-21.

Cite this article: Shaheen S, Gangwar V, John NA, Gupta S. An Observational Study of Variation in the Pulmonary Functions with the Phases of Menstrual Cycle in Females of Different Age Groups. Int J Clin Exp Physiol. 2020;7(1):22-6. 